Institute of $\mathbf{F}_{\text {ood and }} \mathbf{A}_{\text {gricultural }} \mathbf{S}_{\text {ciences }}$

\title{
Bermudagrass Production in Florida 1
}

\section{G. Chambliss and F. A. Johnson²}

The improved hybrid bermudagrasses (Cynodon dactylon $L$.) are used for both hay and grazing. Coastal was the first hybrid bermudagrass developed at the Coastal Plain Experiment Station in Tifton, Georgia, and was released in 1943. Several other bermudagrass varieties have been developed since then by both public agencies and private individuals. Hybrid bermudagrasses have been popular for hay production because they are very responsive to nitrogen fertilizer, have high yield potential, and usually dry or cure faster than most other forages that could be used for hay. Bermuda makes good use of animal manures and so has been widely used by the poultry and dairy industries. Overseeding of winter forages has generally been more successful on bermudagrasses than on bahiagrasses. Many research studies have shown high animal weight gains per acre when bermuda is well fertilized.

\section{BERMUDAGRASS VARIETIES}

The following is a list of varieties that can be used in Florida: Coastal, Suwannee, Coastcross-1, Callie, Alicia, Tifton 44, Tifton 78, Tifton 85, and Florakirk. Stargrasses are closely related to the bermudagrasses, and several varieties are available. The newer varieties were developed primarily for increased yield and quality.

Coastal was the first improved forage bermudagrass. It has proven to be well adapted in north Florida and has performed well for many years.

Suwannee was released in 1953 and is similar to Coastal but will out-yield Coastal when grown on the very drought susceptible deep sands.

Coastcross-1 was released in 1967. It is much more digestible than Coastal, but has less cold tolerance. It may be subject to winter-killing in severe winters. It spreads rapidly by above ground stolons, and develops few, if any, rhizomes. It is now grown only in the warmer areas of peninsular Florida for hay production.

Callie is more digestible and higher yielding than Coastal but is susceptible to rust disease which may become severe if the grass is not harvested on a 4 to 5-week schedule. Callie produces few rhizomes, and therefore it is suggested that it is best established by planting the green tops instead of sprigs.

1. This document is SS-AGR-60, one of a series of the Agronomy Department, Florida Cooperative Extension Service, Institute of Food and Agricultural Sciences, University of Florida. This publication is also part of the Florida Forage Handbook, an electronic publication of the Agronomy Department. For more information you may contact the editor of the Florida Forage Handbook, C. G. Chambliss (cgc@ mail.ifas.ufl.edu). Revised June 2002. Please visit the EDIS Website at http://edis.ifas.ufl.edu.

2. C. G. Chambliss, associate professor, Agronomy Department; and F. A. Johnson, professor, Entomology/Nematology Department, Cooperative Extension Service, Institute of Food and Agricultural Sciences, University of Florida, Gainesville, 32611.

The use of trade names in this publication is solely for the purpose of providing specific information. It is not a guarantee or warranty of the products named and does not signify that they are approved to the exclusion of others of suitable composition.

The Institute of Food and Agricultural Sciences is an equal opportunity/affirmative action employer authorized to provide research, educational information and other services only to individuals and institutions that function without regard to race, color, sex, age, handicap, or national origin. For information on obtaining other extension publications, contact your county Cooperative Extension Service office. Florida Cooperative Extension Service/Institute of Food and Agricultural Sciences/University of Florida/Christine Taylor Waddill, Dean. 
Alicia was introduced to producers by a private individual from Texas. It's ease of establishment and yield is similar to Coastal, but it is the least digestible of the bermudagrasses, and is generally not recommended.

Tifton 44 is more digestible than Coastal and is more cold-hardy than any of the other bermudagrasses. It is more difficult to establish than other bermudagrasses and should be established from sprigs.

Tifton 78 was more digestible and higher yielding than Coastal in research studies at Tifton, GA, and Gainesville, FL. But, producers have had erratic results with both establishment and persistence on Florida's sandy soils.

Tifton 85 was developed and released by Dr. Glenn Burton's breeding program at the Coastal Plain Station at Tifton, Georgia. It is more digestible than Coastal and has produced both higher hay yield and animal weight gain than Coastal. It has performed well in Florida and has been widely accepted by producers. It has larger stems than Coastal, and this, along with higher yield, may increase hay drying time as compared to Coastal.

Florakirk is a new release by the University of Florida/IFAS. It is a sister line to Tifton 78 , but in long term studies at both the Ona, FL and Jay, FL Research and Education Centers it was easier to establish, more persistent, and more productive than Tifton 78. It is a fine-stemmed bermudagrass recommended for hay production in the panhandle and North Peninsular Florida.

Stargrasses are closely related to the bermudagrasses, but are different species. These grasses do not have sufficient cold tolerance to be grown in north Florida, but can be grown in south Florida. They are generally better adapted and more productive when planted on the south Florida flatwoods as compared to the hybrid bermudagrasses. Thus they might be considered as a substitute for bermudagrass in that area. They have large stems and are not favored in some hay markets even though their nutritional value may be equal to or greater than that of the finer stemmed bermudagrasses.

\section{ESTABLISHMENT}

Establishment of a bermudagrass hay field or pasture is a major expense. Producers should do all that is possible to insure success.

The following suggestions may be helpful in successfully establishing bermudagrasses.

\section{Site Selection and Land Preparation: a)} choose a reasonably well-drained soil; b) destroy common bermudagrass and other weeds by keeping the soil cultivated (fallow) over an extended time period, especially during dry weather. It may be preferable to spray spots of common bermudagrass with Roundup ${ }^{\circledR}$ herbicide in the growing season prior to establishment.

2. Lime and Fertilization: Raise soil $\mathrm{pH}$ to 5.5 by liming. Use dolomitic limestone if a soil test indicates a need for magnesium. If in the future you plan to overseed your bermudagrass with a small grain or ryegrass, adjust the $\mathrm{pH}$ to 6.0 and to 6.5 for clovers. For sandy soils, apply soil test recommended rates of phosphorus $(\mathrm{P})$ and potassium $(\mathrm{K})$, along with 30 pounds of nitrogen per acre as soon as the bermudagrass plants start to grow. Apply an additional 70 pounds of nitrogen per acre and one-half of the recommended potassium when stolons (runners) begin to develop.

3. Time of planting: The improved hybrid bermudagrasses do not produce sufficient seed and must be established from vegetative plant parts. Dug sprigs, consisting of underground rhizomes, plant crowns and stolons, can be planted from mid-February through July. Sprigging bermudagrass in mid to late winter before it starts growing (before breaking dormancy) is encouraged. Sprigs dug in early spring after the plants have broken dormancy will have lower levels of energy reserves. Energy reserves are needed to initiate and develop new shoots (sprouts). Also, soil moisture is usually more favorable in late winter as compared to spring (April -May). In the spring, when top growth reaches four to six inches, digging and planting of sprigs should be delayed until after the first hay harvest or harvest of tops for planting. Tops (green stems) can be planted in June and July. The grass should be overly mature 
with six weeks or more of growth when the tops are harvested for planting.

When planting tops, try to plant during a cloudy, rainy period. Moisture conditions must be ideal for this method to succeed. The soil becomes very hot during clear, bright summer days and the planting material can either dry out or "scald". This seems to be more of a problem with tops than with dug sprigs. Also, chances of success when using tops are likely greater when planting on flatwoods as compared to upland deep sands.

If possible, all plantings should be completed no later than mid-August. Fall plantings have been successful in some years in peninsular Florida, but as a general rule fall planting is not recommended because of the possibility of damage from drought or an early freeze. Young plants should be allowed plenty of time (three months) to develop a strong root system before cold weather.

4. Planting Material: Obtain planting material (sprigs or tops) from nurseries that are pure as to variety and free from common bermudagrass or other weedy grasses. Plant fresh, pure, live sprigs or freshly cut tops that are six weeks old or older. Sprigs can be dug with a commercial sprig digger. They can also be harvested by using a spring-tooth harrow or field cultivator, along with a side-delivery rake and pitch fork. Green tops can be harvested with conventional hay equipment. Balers can be adjusted to form small bales that will weigh whatever is needed for ease of handling. Green bales should be moved and planted quickly before they go through a heat.

5. Planting rate: Plant 30 to 40 bushels of dug sprigs, or approximately 1500 pounds of tops per acre. Higher planting rates can be used to insure rapid development of a good stand if planting material is readily available or low in cost. One bushel is 1.25 cubic feet.

6. Planting Method: Always plant in a well-prepared, weed-free, moist seedbed. Land that has been turned with a moldboard plow or has received other primary tillage should be smoothed with a disk harrow to destroy germinating weed seeds just ahead of the planter. Dug sprigs can be planted with commercial sprig planters that place the sprigs in the soil two to three inches deep. Tree planters and other machines have also been used. Both dug sprigs and tops can be broadcast on the surface with a spinner-type grass planter. Other planting devices are also available that broadcast large roll bales of green tops. The planting material should be immediately covered with a disk harrow to depth of 2 to 3 inches. Long tops (stems) can also be pushed into the soil with a "fairway" type roller. Pack the soil with a heavy roller so that soil capillarity can be established which will keep the soil moist around the planting material.

\section{Establishment Weed Control: Spray} immediately after planting (same day) with $2 \mathrm{lb} / \mathrm{acre}$ of 2,4-D or other suitable preemergence herbicide. In 30 to 40 days after planting, an application of 2,4-D, or other similar herbicide, may be needed for control of any broadleaf weeds that escape the initial herbicide treatment. Contact your county agricultural agent for updates on herbicide recommendations. These can be found in the "Weed Control Guide" or in the publication "Weed Control in Pastures and Rangeland," in the series "Weeds in the Sunshine."

With sustained soil moisture, good weed control, and adequate fertility, bermudagrass can be established in three months and ready for the first hay harvest or light grazing. Late plantings should not be harvested, but allowed to go through the winter with plenty of top growth.

When a producer intends to establish a large acreage it may be wise to first establish a smaller area as a nursery. From the nursery the producer can harvest planting material for additional plantings. This practice spreads the risk of establishment failure over more than one season.

\section{FERTILIZATION FOR HAY AND GRAZING}

Bermudagrasses require fertilization to produce high yields. They are very responsive to nitrogen. The initial application of fertilizer each year should be applied when the grass starts growing, which is usually in March (February in South Florida). For hay production apply 80 pounds of nitrogen per acre and soil test recommended amounts of $\mathrm{P} \& \mathrm{~K}$ in early 
spring. After each cutting, except the last in the fall, apply an additional $80 \mathrm{lb} \mathrm{N}$, and $40 \mathrm{lb} \mathrm{K} \mathrm{l}_{2} \mathrm{O} / \mathrm{a}$, along with $20 \mathrm{lb} \mathrm{P}_{2} \mathrm{O}_{5} / \mathrm{A}$ if the soil tested low or medium in P. For grazing apply 80 pounds of nitrogen per acre and soil test recommended amounts of P \& K. An additional 80 pounds of $\mathrm{N}$ can be applied mid-season if needed. Sulfur is not recommended and in most situations a growth response to sulfur would not be expected. As insurance against a potential sulfur deficiency, some producers are applying part of their nitrogen as ammonium sulfate, but a premium should not be paid for this source of nitrogen, relative to that of other nitrogen sources, simply for the insurance against a potential sulfur deficiency. If manure is used as a fertilizer, it will supply sulfur. The need for routine use of micronutrients has not been demonstrated.

When using manure, if possible, determine the nutrient content of the manure being used and then apply the manure in amounts needed to supply the N, $\mathrm{P}, \mathrm{K}$ nutrient recommendations. Additional N, P or K may be needed to supplement the manure.

With the use of high nitrogen rates, $\mathrm{pH}$ will decrease over time. Ammonium sulfate lowers $\mathrm{pH}$ faster than other sources of nitrogen. Use annual soil testing to follow the decrease in $\mathrm{pH}$ and to determine $\mathrm{P}$ and $\mathrm{K}$ levels. A good time to take soil samples is in the fall after the last hay harvest. Be especially careful not to fall behind in potassium application. Low potassium levels have resulted in thinning of stands.

Bermudagrass is especially responsive to nitrogen. Table 1 presents estimates of crude protein and dry matter yield (3-5\% moisture hay) for increasing amounts of nitrogen applied. Estimates of nitrogen removal in the harvested crop are also given.

\section{HAY MANAGEMENT}

The first hay harvest should be made when there is enough forage to justify equipment use. At this time the grass may be 14 to 16 inches high.

Try to take the first harvest before summer rains start. Be ready to take each successive harvest at four weeks of regrowth. If the weather does not allow harvest at four weeks, harvest at five or six weeks.
Maximum yield is usually obtained with a six week schedule. However, waiting until six weeks to harvest may result in further delays due to rain. If harvest is delayed beyond six weeks, quality (digestibility and protein) decreases rapidly. The effect of cutting interval on hay quality is shown in Table 2 and Table 3.

Animal intake is higher and gain per animal is greater with bermudagrass that is four weeks old when harvested. Cutting interval, or age of forage when harvested, affects both digestibility and protein level. Both decrease as cutting interval increases. High rates of nitrogen fertilizer will tend to raise the protein level. Make every effort to avoid rain when cutting, drying and baling the hay. If the hay is rained on, use a tedder after the rain to help speed drying. A heavy rain will leach some soluble sugars out of the leaves, thus reducing the quality of the hay to some extent. A greater problem may be the growth of molds and other rotting organisms if the rain continues for several days or if the grass is baled too wet.

Hay producers can use an electronic moisture tester to determine when the grass is dry enough to bale. The moisture content should be at $15 \%$ or lower before baling in order to prevent the growth of molds and heating. Bales that are too wet can present a fire hazard through spontaneous combustion. Some producers have used hay preservatives (organic acids) that inhibit the growth of molds. This allows them to bale at moisture levels up to about $22 \%$. The preservative is applied to the grass as it enters the bale chamber.

When frequent rainfall does not permit drying and conserving the grass as hay, roll bale silage may be an alternative to consider. The roll bale silage system uses a conventional large round baler to roll up wet grass (55-65\% moisture). The bale is then wrapped in stretch plastic to exclude oxygen. This requires a special machine to apply the plastic wrap. Because of extra expense, the roll bale silage system should only be used to conserve young high quality grass and only when the weather is too wet to make hay. 
Bermudagrass can be conserved by using a conventional silage system (field chopper, wagons, silos). Such a system requires considerable investment in equipment, but it is being used successfully by large dairy operations throughout the state. The big advantage of a silage system is that it is not weather dependent. Grass can be harvested on a four to five week schedule.

\section{GRAZING MANAGEMENT}

Management of bermudagrass for grazing is somewhat similar to that for hay. Young immature grass is more nutritious than old mature grass.

Heavier fertilization (more than $50 \mathrm{lbs}$ N/acre), rotational grazing and mowing as needed to keep the grass young and tender will result in highest animal production. Having the bermudagrass area divided into several pastures will allow for rotational grazing, and for mechanical harvest of excess production during the summer as hay or silage.

A three-year grazing study was conducted at the Georgia Coastal Plain Experiment Station where yearling beef steers were used to compare Tifton 85 with Tifton 78. Both are high yielding, high quality hybrid bermudagrasses. This study ( Table 4 ) shows the potential for high animal gain that can be obtained from well-fertilized hybrid bermudagrass.

Average daily gain was similar for Tifton 78 and Tifton 85 , but Tifton 85 produced 46 percent higher gain per acre compared to Tifton 78 . Additional steers were added to the Tifton 85 pastures during the summer to utilize the extra forage produced.

\section{WEED CONTROL}

Maintaining a vigorous healthy stand of bermudagrass will help prevent weed invasion. In spite of following all of the recommended liming, fertilization, grazing, and hay production practices, a weed problem may occasionally develop. Many broadleaf weeds can be controlled in both bermudagrass pastures and hayfields with timely applications of 2,4-D, Banvel, Remedy, Weedmaster or Crossbow. Pensacola bahiagrass can be controlled with Ally. Velpar can be used for smutgrass control (be sure to check grazing and haying restrictions before application).
Spot treatment of common bermuda with Roundup in a hybrid bermudagrass nursery is useful; however, the hybrid bermudagrass will be injured or killed in the treated area.

\section{Details on use of all the herbicides mentioned above are provided in the publication "Weed Control in Pastures and Rangeland" in the Weeds in the Sunshine series and also in the Weed Control Guide. Annual updates of this information can be obtained from your county agricultural extension office. Before using any herbicide, always read and study the label carefully. The label will provide information on the time period that must elapse between application of herbicide and resumption of grazing or removal as hay.}

\section{INSECTS}

Armyworms, striped grass loopers and grasshoppers may occasionally be a problem usually in the summer and fall and especially on bermudagrass fields that have been recently fertilized. These insects feed on the leaves and can completely strip a field of bermudagrass if not detected in time. If an infested field is to be harvested for hay, and the grass is long enough when infestation occurs, go ahead and harvest. If it can be utilized by grazing, do so. But, if the grass is not ready to be harvested, an insecticide can be used to control the worms. Insecticides work best if applied when the worms are small. It is probably a good idea to check bermudagrass fields for worms during the summer and fall by walking the fields on a weekly basis and watching for cattle egrets and other birds that might be feeding on the worms.

Spittlebug is another insect that can damage bermudagrass. The presence of the insect is indicated by a white froth or spittle-like material at the base of the plant which contains the young immature insect. Adults emerge from the froth as dark brown or black flying insects that are about $3 / 8$ of an inch long with two orange-red lines across the wings. Spittlebugs appear in June and late August. When feeding, the adults and immature stages inject a toxin into the plant that causes the leaves to turn brown and look frosted. The affected areas enlarge as the adults spread and feed. Mowing or grazing to keep the grass 
from growing tall, lodging, and becoming densely matted will prevent most spittlebug problems.

Burning of the bermudagrass in February or just prior to "green up" will help to control spittlebug by killing the over-wintering eggs and early immature stages of the insect. There is a small risk involved when this practice is used on a less cold tolerant variety such as Coastcross-1. Burning will stimulate the grass to start growing earlier and faster. If a late hard freeze in March hits this young tender growth, the plant could be killed. Use of insecticides is usually not feasible. The young insects are protected by the spittle mass and the insecticide must be timed to contact the adults in either June or September to be effective which means the grass must be grazed short or mechanically harvested. Contact your county extension agricultural agent for the latest update on recommended insecticides.

\section{DISEASES}

Diseases are usually not a serious problem as long as the grass is harvested on a four to five week schedule. Helminthosporium is the most common disease found on bermudagrasses and large areas of what appears to be frosted grass may develop in the field. Keeping the potassium levels up, burning the fields just before green up, and harvesting the grass on a regular schedule will help prevent the occurrence of this disease. 


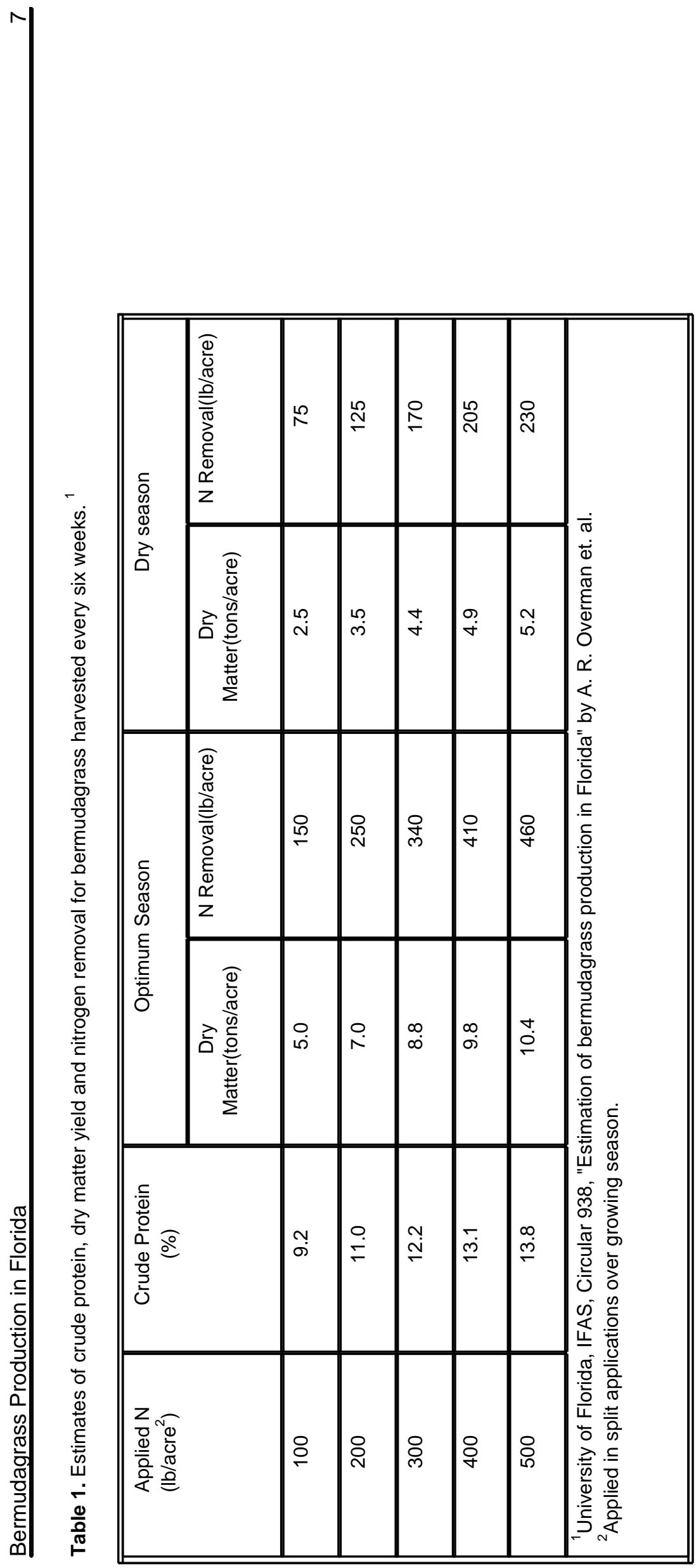


Table 2. Effect of cutting intervals on dry matter intake, digestibility, and daily gain per animal of Coastal bermudagrass hay (Ga). ${ }^{1}$

\begin{tabular}{||c|c|c|c|}
\hline \hline Cutting Interval(weeks) & Dry Matter Intake(lb/day) & Forage Digestibility(\%) & Average Daily Gain(Ibs) \\
\hline 4 & 11.8 & 55 & 1.2 \\
\hline 8 & 9.3 & 45 & 0.9 \\
\hline 13 & 9.5 & 0.0 \\
\hline${ }^{1}$ From Circular 557, University of Florida Cooperative Extension Service, Wright et al. & \\
\hline \hline
\end{tabular}

Table 3. Effect of maturity on crude protein (CP), total digestible nutrients and quality index of bermudagrasses. ${ }^{1}$

\begin{tabular}{||c|c|c|c|}
\hline \hline Weeks of Regrowth & CP & TDN $^{2}$ \\
\hline 2 & 16.0 & 56.3 & 1.38 \\
\hline 4 & 13.6 & 57.1 & 1.34 \\
\hline 6 & 9.0 & 52.6 & 1.21 \\
\hline 8 & 7.5 & 47.9 & 1.00 \\
\hline 10 & 8.3 & 46.1 & 0.92 \\
\hline $\begin{array}{l}{ }^{1} \text { Data summarized from several experiments, University of Florida. } \\
{ }^{2} \text { Percent of dry matter (Source - John E. Moore, University of Florida). } \\
{ }^{3} \text { Quality Index is voluntary intake of TDN as a multiple of maintenance. }\end{array}$ & \\
\hline \hline
\end{tabular}

Table 4. Three-year performance of steers grazing Tifton 78 or Tifton 85 pastures. ${ }^{1}$

\begin{tabular}{||l|c|c|c||}
\hline \hline Grass & Steer Grazing Daysper acre & Live Weight Gain(lb/acre) & Average Daily Gain(lb) \\
\hline Tifton 85 & 704 & 7032 & 1.47 \\
\hline Tifton 78 & 534 & 1.43 \\
\hline $\begin{array}{l}\text { 1'Data from G. M. Hill, et al. (1993) Journal of Animal Science 71:3219. Fertilized annually with 225 pounds of nitrogen in 3 split } \\
\text { applications plus adequate P and K. Pastures were grazed from April to October. }\end{array}$ \\
\hline \hline
\end{tabular}

